\title{
DIETARY PATTERNS OF HEALTH SCIENCES STUDENTS IN REGARDING TO PHYSICAL ACTIVITY LEVELS AND SOMATIC INDICATORS OF NUTRITIONAL STATUS
}

\author{
Robert Gajda', Monika Bronkowska ${ }^{1}$
}

${ }^{1}$ Wrocław University of Environmental and Life Sciences, Faculty of Biotechnology and Food Sciences, Department of Human Nutrition, Wrocław, Poland

\begin{abstract}
Background. In extensive world literature, there is no relationship has been noted between dietary patterns defined a posteriori ("data driven") and metabolic risk indicators, especially among medical and health science students.

Objective. The aim of the study was recognition of dietary patterns defined a posteriori ("data driven") among students in discipline of Health Sciences in regarding to their levels of physical activity, as well as selected nutritional status indicators.

Material and methods. The studied population group consisted of 609 respondents aged 19 - 30. Data was collected on: the frequency of consumption of 16 groups of food products, levels of physical activity, body weight and hight. Based on the data, the somatic indicators were calculated: BMI (Body Mass Index), WC (Waist Circumference) and WHtR (Waist to Hight Ratio). Four dietary patterns were identified using factor analysis, i.e. including two health-promoting factors, "vegetables and fruits" and "milk, fermented milk drinks and cottage cheese", and two non-health-promoting factors, "carbonated drinks, energy drinks, alcohol and canned food" and "fast food and confectionery products". The relationship between levels of physical activity, somatic indicators and dietary patterns was tested using the Chi-square test.

Results. Respondents with a high level of physical activity were statistically significantly more often characterized by high intensity of all health-promoting dietary patterns and low intensity of one unhealth-promoting dietary patterns such as "fast food and confectionery products". There was no statistically significant differentiation between underweight and normal body weight according to the BMI criteria or differentiation according to the severity of separate dietary patterns, but such a difference was found between overweight according to the BMI criteria and obesity according to the BMI and WC criteria. There was often a statistically significant relationship between overweight and obesity according to the BMI and visceral obesity with a high risk of metabolic complications according to the WC index, and a high intensity of unhealthy dietary patterns was more often observed than a high intensity of health-promoting dietary patterns.

Conclusion. Effective programs and methods of nutritional education and motivation to change health behaviours should be implemented among students of Health Sciences, especially those who are overweight or obese, or have lower activity level values.
\end{abstract}

Key words: dietary patterns, physical activity, somatic indicators, students

\section{STRESZCZENIE}

Wprowadzenie. W literaturze światowej nie dostrzega się badań oceniających związek wzorów żywieniowych zdefiniowanych a 'posteriori („,data-driven”) ze wskaźnikami ryzyka chorób metabolicznych szczególnie wśród studentów medycyny i nauk o zdrowiu.

Cel badań. Celem badania było rozpoznanie wzorów żywieniowych zdefiniowanych a posteriori ("data driven") wśród studentów Nauk o Zdrowiu w odniesieniu do ich poziomów aktywności fizycznej i wybranych wskaźników stanu odżywienia.

Material i metody. Badaną grupę populacyjną stanowiło 609 respondentów w wieku 19-30 lat. Zebrane dane dotyczyły: spożycia 16 grup produktów żywnościowych, poziomów aktywności fizycznej, masy ciała i wzrostu. Na podstawie zebranych danych obliczono wskaźniki somatyczne: BMI (Body Mass Index), WC (Waist Circumference) and WHtR (Waist to Hight Ratio). Za pomocą analizy czynnikowej zidentyfikowano 4 wzory żywieniowe, obejmujące dwa czynniki sprzyjające zdrowiu, tj.: "owoce i warzywa" oraz "mleko, mleczne napoje fermentowane i twarogi” i dwa czynniki nie sprzyjające zdrowiu, tj.: "napoje gazowane, energetyczne, alkohole i konserwy" oraz "fast food i wyroby cukiernicze". Związek między poziomem aktywności fizycznej, wskaźnikami somatycznymi i wzorami żywieniowymi badano z użyciem testu Chi-kwadrat.

Corresponding author: Robert Gajda, Uniwersytet Przyrodniczy we Wrocławiu, Wydział Biotechnologii i Nauk o Żywności, Katedra Żywienia Człowieka, ul. Chełmońskiego 37, 51-630 Wrocław, tel. +48 71 3207758, e-mail: robert.gajda@upwr.edu.pl

(C) Copyright by the National Institute of Public Health - National Institute of Hygiene 
Wyniki. Respondenci o wysokim poziomie aktywności fizycznej statystycznie istotnie częściej charakteryzowali się wysoką intensywnością wszystkich wzorów żywieniowych sprzyjających zdrowiu oraz niską intensywnością wzoru żywieniowego nie sprzyjającego zdrowiu tj.: "fast food i wyroby cukiernicze". Nie stwierdzono statystycznie istotnego zróżnicowania między niedowagą i prawidłową masą ciała według kryteriów wskaźnika BMI a nasileniem wzorów żywieniowych, ale stwierdzono takie zróżnicowanie w przypadku nadwagi według kryteriów wskaźnika BMI oraz otyłością według kryteriów wskaźników BMI i WC. Częściej obserwowano statystycznie istotną zależność między nadwagą i otyłością według kryteriów wskaźnika BMI oraz otyłością brzuszną z wysokim ryzykiem powikłań metabolicznych według wskaźnika WC i wysoką intensywnością wzorów żywieniowych nie sprzyjających zdrowiu, niż wysoką intensywnością wzorów żywieniowych sprzyjających zdrowiu.

Wnioski. Skuteczne programy i metody edukacji żywieniowej oraz metod zmiany zachowań żywieniowych powinny być wdrożone wśród studentów Nauk o Zdrowiu, szczególnie wśród tych z nadwagą i otyłością lub niskim poziomem aktywności fizycznej.

Słowa kluczowe: wzory żywieniowe, aktywność fizyczna, wskaźniki somatyczne, studenci

\section{INTRODUCTION}

Dietary patterns represent a set of many characteristics, common features describing the diet of different people or population groups. These features can determine the type and amount of nutrients, food or food groups, as well as the frequency of having meals or preferring or avoiding specific foods [11]. Analysis of dietary patterns is considered a holistic approach to assessing the relationship between diet and the risk of chronic disease. Instead of looking for the effects of individual nutrients or food, dietary patterns evaluate the impact of an entire diet and its complexity $[11,15,29]$.

Studies on dietary patterns are carried out mainly to assess the relationship between them and the occurrence of chronic diseases [11]. In the world literature, there is a relationship between health-promoting dietary patterns defined a priori (,hypothesis driven”), e.g. HEI (Healthy Eating Index), AHEI-2010 (Alternative Healthy Eating Index 2010) HDI (Healthy Diet Index), DQI (Diet Quality Index), AMED (the Alternative Mediterranean Diet score), or DASH (the Dietary Approach to Stop Hypertension), and risk indicators of metabolic diseases, e.g. somatic [23], biochemical [11] or physical activity [16, 18]. Studies assessing the relationship of dietary patterns defined a posteriori (,data driven”) with metabolic disease risk indicators, especially among medical and health sciences students, are not seen.

From the perspective of the above data, the purpose of the work was to identify dietary patterns selected on the basis of the dataset characteristics ("data driven") for students of Health Sciences in regarding to their levels of physical activity and selected somatic indicators of the nutritional status of these students.

\section{MATERIAL AND METHODS}

This cross-sectional study was carried out between October and December 2018 among full-time students. The studied population group consisted of
609 respondents aged 19-30. Students represented two universities. The surveyed students were educated in six fields in the discipline of Health Sciences, i.e. cosmetology - 233 people, dietetics - 165 people, physiotherapy - 96 people, emergency medical services -57 people, nursing -49 people and electroradiology -9 people. The detailed characteristics of the studied population group in terms of the level of physical activity and selected somatic indicators, taking into account the sex and age of the subjects, are presented in Table 1.

The study was conducted using a questionnaire. The study sample was selected arbitrarily, i.e. a survey was conducted, and the waist circumference (WC) of all students present at the university who agreed to participate was measured on the day of the study. As a result of the study, 609 surveys were collected, including 609 waist circumference measurements.

The survey used in the study consisted of two research tools. The first of these was the QEB questionnaire for researching nutritional behaviours and opinions on food and nutrition developed by the Group of Behavioural Nutrition Conditions of the Committee on Science of Human Nutrition PAN. Based on the QEB questionnaire, intake was assessed for 16 groups of food products by using a 6-grade intake frequency scale, where grade 1 meant "never" and grade 6 "several times a day". The second research tool was the shortened version of the IPAQ (International Physical Activity Questionnaire), enabling the collection of information on various forms of physical activity of respondents over the last 7 days. The collected data on weekly physical activity were calculated according to a strictly defined scheme into MET units (Metabolic Equivalent of Task) [12]. On the basis of physical activity expressed in MET units (MET-minutes/week), people with moderate (600-3000 MET-minutes/week) and high levels of physical activity (>3000 MET-minutes/week) were distinguished. None of the subjects had low levels of physical activity ( $<600$ MET-minutes/week). In addition, as part of the survey, respondents were asked 
Table 1. Characteristics of the studied population group [\%]

\begin{tabular}{|c|c|c|c|c|c|c|c|}
\hline \multirow[b]{2}{*}{ Features of the population group } & \multirow{2}{*}{$\begin{array}{r}\text { Generally } \\
(\mathrm{n}=609)\end{array}$} & \multicolumn{2}{|c|}{ Gender } & \multicolumn{4}{|c|}{ Age (in years) } \\
\hline & & $\begin{array}{c}\text { men } \\
\mathrm{n}=106)\end{array}$ & $\begin{array}{l}\text { women } \\
\mathrm{n}=503\end{array}$ & $\begin{array}{c}19-21 \\
n=430\end{array}$ & $\begin{array}{c}22-24 \\
\mathrm{n}=128\end{array}$ & $\begin{array}{l}25-27 \\
\mathrm{n}=34\end{array}$ & $\begin{array}{l}28-30 \\
\mathrm{n}=17\end{array}$ \\
\hline Generally & 100.0 & 17.4 & 82.6 & 70.6 & 21.0 & 5.7 & 2.7 \\
\hline \multicolumn{8}{|c|}{ Level of physical activity } \\
\hline $\begin{array}{l}\text { moderate } \\
\text { high }^{\mathrm{P}, \mathrm{W}}\end{array}$ & $\begin{array}{l}24.7 \\
75.3\end{array}$ & $\begin{array}{l}16.0 \\
84.0\end{array}$ & $\begin{array}{l}26.4 \\
73.6\end{array}$ & $\begin{array}{l}23.5 \\
76.5\end{array}$ & $\begin{array}{l}28.3 \\
71.7\end{array}$ & $\begin{array}{l}20.0 \\
80.0\end{array}$ & $\begin{array}{l}42.9 \\
57.1\end{array}$ \\
\hline \multicolumn{8}{|c|}{ Selected somatic indicators } \\
\hline $\begin{array}{l}\text { BMI } \\
\text { underweight } \\
\text { norm } \\
\text { overweight } \\
\text { obesity }^{\mathrm{P}, \mathrm{w}}\end{array}$ & $\begin{array}{c}10.0 \\
73.8 \\
13.8 \\
2.4 \\
\end{array}$ & $\begin{array}{c}1.9 \\
59.4 \\
33.0 \\
5.7 \\
\end{array}$ & $\begin{array}{c}11.7 \\
76.9 \\
9.7 \\
1.6\end{array}$ & $\begin{array}{c}11.4 \\
73.7 \\
13.0 \\
1.9 \\
\end{array}$ & $\begin{array}{c}6.3 \\
76.4 \\
12.6 \\
4.7 \\
\end{array}$ & $\begin{array}{c}8.6 \\
77.1 \\
14.3 \\
0.0 \\
\end{array}$ & $\begin{array}{c}5.9 \\
52.9 \\
41.2 \\
0.0 \\
\end{array}$ \\
\hline $\begin{array}{l}\text { WHtR } \\
\text { norm } \\
\text { visceral obesity }\end{array}$ & $\begin{array}{l}79.5 \\
20.5\end{array}$ & $\begin{array}{l}65.1 \\
34.9\end{array}$ & $\begin{array}{c}82.9 \\
17.1\end{array}$ & $\begin{array}{l}82.3 \\
17.7\end{array}$ & $\begin{array}{l}72.4 \\
27.6\end{array}$ & $\begin{array}{l}77.1 \\
22.9\end{array}$ & $\begin{array}{l}64.7 \\
35.3\end{array}$ \\
\hline $\begin{array}{l}\text { WC } \\
\text { norm } \\
\text { *visceral obesity with IR of MC }^{* *} \text { visceral obesity with } \mathrm{HR} \text { of } \mathrm{MC}^{\mathrm{w}}\end{array}$ & $\begin{array}{c}78.8 \\
14.1 \\
7.1\end{array}$ & $\begin{array}{l}75.5 \\
17.9 \\
6.6\end{array}$ & $\begin{array}{c}79.5 \\
13.3 \\
7.2\end{array}$ & $\begin{array}{c}81.6 \\
12.6 \\
5.8\end{array}$ & $\begin{array}{l}70.1 \\
18.1 \\
11.8\end{array}$ & $\begin{array}{l}80.0 \\
17.1 \\
2.9\end{array}$ & $\begin{array}{l}70.6 \\
17.6 \\
11.7\end{array}$ \\
\hline
\end{tabular}

* Visceral obesity with an increased risk of metabolic complications; ** Visceral obesity with a high risk of metabolic complications

${ }^{\mathrm{P}, \mathrm{W}}$ Statistically significant differences between the feature of the population group according to gender $(\mathrm{P})$ and age $(\mathrm{W})$; level of significance $\mathrm{p} \leq 0.05$ (Chi-squared test)

to provide body weight in kilograms and body height in centimetres. WC was measured in a standing position using anthropometric tape at the greatest narrowing of the torso at the waist, with the abdominals relaxed.

In the statistical analysis, the number and percentage of students with a given feature were used to describe the population structure. During statistical analysis the "data-driven" method was used to extract dietary patterns. The method does not require preliminary assumptions and dietary patterns to be discovered on the basis of the features of the data set $[15,29]$. Factor analysis was used as the method of dietary pattern construction, wherein 6-step response scales reflecting the frequency of consumption were treated as quantitative scales, assuming the existences of a fixed. As a result of the application of the main components method among 16 features (food product groups), four factors (main components) identified on the basis of the correlation coefficient $r \geq 0.5$ were separated. Varimax rotation with normalization was used and achieved convergence in nine iterations (Table 2).

The factors selected as a result of the analysis were described as dietary patterns wherein factor 1 described unhealthy patterns of the type "carbonated drinks, energy drinks, alcohols and canned products"; factor 2, health-promoting patterns of the type "fruits and vegetables"; factor 3 , unhealthy patterns of the type "fast food and confectionery products" and factor 4, health-promoting patterns of the type "milk, fermented milk drinks and cottage cheese". In addition, after triacylic division of the factor values, three qualitative variables of each factor were distinguished and described as low factor intensity (first percentile), moderate factor intensity (second percentile) and high factor intensity (third percentile).

When assessing the somatic parameters (body weight, height, WC), basic nutritional assessment indicators were calculated, i.e. BMI (body mass index), WC (waist circumference) and WHtR (waistto-height ratio). WHO recommendations were adopted as BMI diagnostic criteria for assessing nutritional status [30]. According to these criteria, BMI $<18.5 \mathrm{~kg} / \mathrm{m}^{2}$ indicates underweight, $18.5-24.9$ $\mathrm{kg} / \mathrm{m}^{2}$ normal weight, $25.0-29.9 \mathrm{~kg} / \mathrm{m}^{2}$ overweight and $\geq 30.0 \mathrm{~kg} / \mathrm{m}^{2}$ obesity. The WHO Report 2008 regarding WC recommendations were adopted as diagnostic criteria for the assessment of abdominal obesity and the risk of metabolic complications associated with it [28]. According to this report, a WC above $94 \mathrm{~cm}$ for men and $80 \mathrm{~cm}$ for women is associated with abdominal obesity with a significant risk of metabolic complications, and values above $102 \mathrm{~cm}$ for men and $88 \mathrm{~cm}$ for women indicate abdominal obesity with a very high risk of metabolic complications. As the WHtR diagnostic criterion for abdominal obesity and an increased risk of heart disease and diabetes, we adopted the cut-off point of 0.5 . A WHtR value $\geq 0.5$ indicates abdominal obesity and an increased risk of these complications $[3,5]$. 
Table 2. Factor load table after varimax rotation with normalization

\begin{tabular}{|l|c|c|c|c|}
\hline \multirow{2}{*}{\multicolumn{1}{|c|}{ Food groups }} & \multicolumn{4}{c|}{ Main components } \\
\cline { 2 - 5 } & Factor 1 & Factor 2 & Factor 3 & Factor 4 \\
\hline Wholemeal bread & $-0.081669 *$ & 0.365991 & -0.031295 & 0.276615 \\
\hline Milk (including flavoured milk) & -0.121347 & -0.001969 & 0.231113 & 0.605702 \\
\hline Fermented milk drinks & -0.023804 & 0.144385 & 0.048491 & 0.779949 \\
\hline Cottage cheese (incl. homogenized and grainy) & 0.114069 & 0.166751 & -0.002955 & 0.713511 \\
\hline Fish preparations and dishes & 0.324804 & 0.271738 & -0.397893 & 0.370605 \\
\hline Legumes dishes & 0.231068 & 0.558948 & -0.275638 & 0.072277 \\
\hline Fruits & -0.193276 & 0.834602 & 0.043821 & 0.125781 \\
\hline Vegetables & -0.112542 & 0.868646 & -0.023847 & 0.034972 \\
\hline Fast food & 0.384493 & -0.188068 & 0.549160 & -0.171010 \\
\hline Fried dishes & 0.154927 & -0.078421 & 0.603051 & 0.106602 \\
\hline Cheese & 0.157405 & 0.049426 & 0.505363 & 0.246706 \\
\hline Sweets and confectionery products & 0.023817 & -0.015154 & 0.711206 & 0.059633 \\
\hline Canned food of all kinds & 0.592384 & -0.068808 & -0.059689 & 0.296348 \\
\hline Carbonated drinks & 0.596532 & -0.082963 & 0.462091 & -0.130269 \\
\hline Energy drinks & 0.590367 & -0.095931 & 0.204770 & -0.063556 \\
\hline Alcoholic drinks & 0.604830 & 0.012824 & 0.112486 & -0.056424 \\
\hline
\end{tabular}

*Value of the correlation coefficient between the feature - a group of food products and the main component

The comparison of qualitative features i.e. the BMI, WC and WHtR criteria, and factors (dietary patterns), including the evaluation of statistically significant differences, was performed by using the Chi-squared test. The significance level was assumed to be 0.05 .

Statistical analysis was performed by using the Statistica Basic 13 PL statistical program.

\section{RESULTS}

Slightly fewer than $25 \%$ of the respondents were characterized by moderate and over $75 \%$ by high levels of physical activity. A high level of physical activity in respondents statistically significantly corresponded to the intensity of three dietary patterns. A statistically significantly higher percentage of surveyed students with a high level of physical activity was characterized by a high intensity of dietary patterns favouring the health-promoting type "fruit and vegetables" as well as "milk, fermented milk drinks and cottage cheese". An inverse dependence was demonstrated for the unhealthy dietary pattern type "fast food and confectionery". In this case, a statistically significantly higher percentage of students with a high level of physical activity was characterized by a low intensity of this dietary pattern (Table 3).

A comparative analysis of the BMI, WC and WHtR criteria showed that approximately $75 \%$ of respondents had somatic values characteristic of body weight due. Overweight and obesity were present $16 \%$ of the surveyed population according to the BMI criteria. Of those surveyed, $10 \%$ were underweight according to the criteria of the same indicator. Over $20 \%$ of respondents were characterized by abdominal obesity according to the criteria of the WC and WHtR indices. The underweight according to the criteria of the BMI index did not statistically significantly differentiate the severity of the identified dietary patterns. Due body weight according to all indicators did not statistically significantly differentiate the intensification of identified dietary patterns. The same situation also applied to the WHtR criterion indicating visceral obesity. A statistically significantly higher percentage of respondents with a high intensity of the unhealthy dietary pattern type "carbonated drinks, energy drinks, alcoholic drinks and canned" was characterized by obesity according to the BMI. In the case of the unhealthy dietary pattern type "fast food and confectionery", a statistically significantly higher percentage of subjects with a high intensity of this pattern was overweight according to the BMI index and abdominal obesity with a high risk of metabolic complications according to the WC index and in the case of moderate severity of this pattern of obesity according to the BMI index. However, a statistically significantly higher percentage of subjects with a high intensity of the health-promoting dietary pattern type "fruit and vegetables" was characterized by overweight and obesity according to the BMI index and visceral obesity with a high risk of metabolic complications according to the WC index. In addition, the moderate severity of the healthpromoting dietary pattern type "milk, fermented milk drinks and cottage cheese" was related to a statistically significantly higher proportion of obese subjects by the BMI index (Table 3). 







\section{DISCUSSION}

There is a general decrease in physical activity in the population. A particularly steep decline in this type of activity concerns young people taking up studies [17, 25]. Brey and Born [4] showed that 1/3 of active high school students became inactive after starting academic life. In the case of Polish students of the Medical University, research by DabrowskaGalas et al. [6] reported that, depending on the field of study, $0-26 \%$ of respondents were characterized by low levels of physical activity, $52-86 \%$ of respondents by moderate levels of physical activity and $8-46 \%$ of respondents by high levels of physical activity. Angyán et al. [2] indicated that medical students were characterized by low levels of physical activity. However, Frank et al. [9] reported that American medical students had higher levels of physical activity than their peers.

Low levels of physical activity and unhealthy dietary patterns are the determinant factors of overweight and obesity $[8,14]$. In turn, the impact of physical activity on dietary patterns is poorly understood [16]. Some cross-sectional studies suggest that young adults who are physically active tend to consume foods with a higher nutritional density and lower energy density, e.g. higher consumption of fruit or dairy products and lower consumption of fast food [7, 13, 22]. In addition, the analysis of three observational cohort studies on the a priori dietary patterns AHEI, AMED and DASH showed that those subjects who adhered to these dietary patterns were more likely to have a higher level of physical activity than those who less adhered to these dietary patterns [8]. Similarly, in our study, it was observed that a statistically significantly higher percentage of people with a high level of physical activity was characterized by a high intensity of the health-promoting dietary pattern of the types "fruits and vegetables" and "milk, fermented milk drinks and cottage cheese" and at the same time with a low intensity of the unhealthy nutrition pattern type "fast food and confectionery". Nevertheless, studies by Koehler et al. [16] suggest that the beneficial effect of increased physical activity on dietary patterns exists only when switching from low to moderate and then from moderate to high levels of physical activity. There is no change in dietary patterns when changing from high to very high physical activity.

In our study, $16.2 \%$ of the student population was characterized as overweight or obese according to the BMI criteria. Similarly, according to another Polish study conducted by Likus et al. [18], overweight and obesity was present in $13.4 \%$ of students. In addition to obesity, another equally important problem for young people is underweight, which affected up to $10 \%$ of respondents in the present study and $9.6 \%$ of students in medicine and health sciences in Likus et al. [18]. It should be pointed out that, while the study showed a relationship between dietary patterns and overweight and obesity according to the BMI and visceral obesity, with a high risk of metabolic complications according to the WC index, no statistically significant difference between the respondents' nutritional patterns and underweight or body mass norm according to the BMI, body mass norm according to WC and WHtR, or visceral obesity according to WHtR.

A statistically significantly higher percentage of respondents with a high intensity of the unhealthy dietary pattern type "carbonated drinks, energy drinks, alcoholic drinks and canned goods" was characterized by obesity according to the BMI. In the case of unhealthy dietary pattern type "fastfood and confectionery", a statistically significantly higher percentage of subjects with a high intensity of this pattern were overweight according to the BMI and had visceral obesity with a high risk of metabolic complications according to the $\mathrm{WC}$ and in the case of moderate severity of this pattern, obesity according to the BMI. Several studies have found a significant relationship between health-promoting a priori dietary patterns and weight loss and visceral obesity [26]. Especially often, such a relationship is observed between the AMED-type dietary pattern and anthropometric indicators [23]. Most crosssectional studies report a strong inverse relationship between adherence to the Mediterranean diet and the prevalence of obesity, and this has been confirmed by cohort studies [23]. The analysis of three observational cohort studies on a priori dietary patterns AHEI, AMED and DASH showed that those subjects who adhered more closely to these nutrition patterns had lower BMI than those who adhered less to these dietary patterns [10]. The research of Sahrai et al. published in 2019 demonstrated that AMED-type pro-healthy dietary patterns statistically significantly corresponded to the lower WC and WHR indicators but did not correspond to the BMI indicator [23]. Such observations are confirmed by the EPIK-PANACEA study, which showed a significant relationship between adherence to the Mediterranean diet and lower waist circumference in men and women, while the relationship between the Mediterranean diet and BMI was not demonstrated [21]. In turn, the results of intervention dietary studies showed that compliance with the Mediterranean diet was associated with lower BMI and significantly lower visceral obesity [1, $10,19]$. In the Sahrai et al. study [23], there was no significant relationship between the HEI or DQI type dietary patterns and the anthropometric indicators WC, WHR and BMI. Regarding HEI-type dietary patterns, a study of Mexican Americans also found no relationship between HEI and waist circumference in 
women, but the results were significant in men [23]. A recent study showed that compliance with DQI was associated with a decrease in WC and BMI in men, while there was no relationship in women [20]. These gender-based differences can be explained by differences in fat storage between men and women. Women tend to store fat around the hips and lower extremities, and men in the abdominal area [31].

Our own study also showed a statistically significantly higher percentage of subjects with obesity according to the BMI index and visceral obesity, with a high risk of metabolic complications according to the WC index characterized by a high intensity of the health-promoting of dietary pattern type "fruit and vegetables" and a moderate severity of the healthpromoting dietary pattern type "milk, fermented milk drinks and cottage cheese", but only for those with obesity according to BMI. This relationship can be explained by the fact that obese study participants can implement a specific diet, e.g. low energy, by consuming more vegetables and fruits [22]. In addition, obese subjects can provide socially desirable answers by underestimating unhealthy foods and overstating healthy foods such as vegetables and fruits [24], which can also be applied to the consumption of milk, fermented milk drinks and cottage cheese.

The main limitations of the study were its design (cross-sectional) and the method used (mainly survey). In addition, the survey showed an exceptionally high proportion of respondents with high levels of physical activity and no respondents with low levels of physical activity in relation to data on the level of student activity in Poland [6]. Most students of the surveyed universities declared that they performed work outside of academic activity, which had an impact on the results of the assessment of the levels of physical activity examined and which could significantly underestimate the relationship between dietary patterns and anthropometric indicators of the respondents. However, the study used the international, standardized IPAQ questionnaire, the most commonly recommended tool for measuring the level of physical activity $[12,27]$ and the research sample was selected arbitrarily and concerned all students in two universities present on the day of the study. Furthermore, only the WC indicator was measured. The body weight and height of respondents were recorded in the study based on self-reported values, which could further reduce the reliability of BMI and WHtR indicators.

\section{CONCLUSIONS}

In conclusion, effective programs and methods of nutritional education and motivation to change health behaviours should be implemented among students of
Health Sciences, especially those who are overweight or obese, or have lower activity level values.

\section{Conflict of interest}

The authors declare no conflict of interest.

\section{REFERENCES}

1. Andreoli A., Lauro S., Di Daniele N., Sorge R., Celi M., Volpe S.L.: Effect of a moderately hypoenergetic Mediterranean diet and exercise program on body cell mass and cardiovascular risk factors in obese women. Eur J Clin Nutr 2008;62:892 doi:10.1038/sj.ejcn.

2. Angyán L., Téczely T., Mezey B., Lelovics Z.: Selected physical characteristics of medical students. Med Educ 2003;8:1 doi: 10,3402/meo.v8i.4328.

3. Bielak J., Krzyszycha R., Szponar B.: Evaluation of dietary habits and other forms of behaviour of students from Lublin. Annales UMCS Section D 2006;61(2):874879.

4. Bray S.R., Born H.A.: Transition to university and vigorous physical activity: Implications for health and phychological well-being. J Am Coll Health 2004;52(4):181 doi:10.3200/JACH.52.4.181-188.

5. Browning L.M., Hsieh S.D., Ashwell M.A.: Systematic review of waist-to-height ratio as a screening tool for the prediction of cardiovascular disease and diabetes: 0,5 could be a suitable global boundary value. Nutr Res Rev 2010;23(2):247 doi: 10.1017/S0954422410000144.

6. Dąbrowska-Galas M., Plinta R., Dąbrowska J., Skrzypulec-Plinta $V$ : Physical activity in students of the Medical University of Silesia in Poland. Phys Ther 2013;93(3):384 doi: 10.2522/ptj.20120065.

7. Deshmukh-Taskar P., Nicklas T.A., Yang S.J., Berenson G.S.: Does food group consumption vary by differences in socioeconomic, demographic, and lifestyle factors in young adults? The Bogalusa heart study. J Am Diet Assoc 2007;107(2):223-234.

8. Ding M., Ellervik Ch., Huang T., Jensen M.K., Curhan G.C., Pasquale L.R., Kang H., Wiggs J.L., Hunter D.J., Willett W.C., Rimm E.B., Kraft P., Chasman D.I., Qi L., $H u$ F.B., Qi Q.: Diet Quality and genetic association with body mass index: results from 3 observational studies. Am. J Clin Nutr 2018;108:1291 doi:10.1093/ajcn/ngy203.

9. Frank E., Tong E., Lobelo F., Carrera J., Duperly J.: Physical activity levels and counseling practices of US medical students. Med Sci Sports Exerc 2008;40:413 doi:10.1249/mss.0b013e31815ff399.

10. Goulet J., Lamarche B., Nadeau G., Lemieux S.: Effect of a nutritional intervention promoting the Mediterranean food pattern on plasma lipids, lipoproteins and body weight in healthy French-Canadian women. Atherosclerosis 2003;170:115 doi:10.1016/S00219150(03)00243-0.

11. Hu F.B.: Dietary pattern analysis: a new direction in nutritional epidemiology. Current Opinion in Lipidiology 2002;13:3 doi:10.1097/00041433-200202000-00002.

12. International Physical Activity Questionnaire, scoring protocol. 2018. Available: http://www.ipaq.ki.se/ scoring.htm (Accessed 28.06.2018). 
13.Jago R., Nicklas T., Yang S.J., Baranowski T., Zakeri I., Berenson G.S.: Physical activity and health enhancing dietary behaviors in young adults: Bogalusa Heart Study. Prev Med 2005;41(1):194 doi:10.1016/j. ypmed.2004.09.045.

14.Janssen I., Katzmarzyk P.T., Boyce W.F., Vereecken C., Mulvihill C., Roberts $C$., Currie $C$., Pickett $W$ : Comparison of overweight and obesity prevalence in school-aged youth from 34 countries and their relationship with physical activity and dietary patterns. Obes Rev 2005;6:123 doi:10.1111/j.1467789X.2005.00176.x.

15. Kant A.K.: Dietary patterns: biomarkers and chronic disease risk. Appl Physiol Nutr Metab 2010;35:199 doi:10.1139/H10-005.

16. Koehler K., Boron J.B., Garvin T.M., Bice M.R., Stevens $J . R .:$ Differential relationship between physical activity and intake of added sugar and nutrient-dense: A crosssectional analysis. Appetite 2019;140:91 doi.10,1016/j. appet.2019.05.010.

17. Kwan M.Y., Cairney J., Faulkner G.E., Pullenavegum E.E.: Physical activity and other health-risk behaviours during the transition into adulthood: A longitudinal cohort study, Am J Prev Med 2012;42(1):4 doi:10.1016/j. amepre.2011.08.026.

18.Likus W., Milka D., Bajor G., Jachowicz-Lopata M., Dorzak B.: Dietary habits and physical activity in students from the medical university of Silesia in Poland. Rocz Państw Zakl Hig 2013;64(4):317-324.

19. Martinez-Gonzalez M.A., Garcia-Arellano A., Toledo E., Salas-Salvado J., Buil-Cosiales P., Corella D., Covas, M.I., Schroder H., Aros F., Gomez-Gracia E., et al:: A 14-item Mediterranean diet assessment tool and obesity indexes among high-risk subjects: The PREDIMED trial. PLoS ONE 2012;7(8):e43134 doi:10.1371/journal.pone.0043134.

20.Mertens E., Deforche B., Mullie P., Lefevre J., Charlier $R$. ., Knaeps S., Huybrechts I., Clarys P.: Longitudinal study on the association between three dietary indices, anthropometric parameters and blood lipids. Nutr Metab 2015;12:47 doi: 10.1186/s12986-015-0042-1.

21. Romaguera D., Norat T., Vergnaud A.C., Mouw T., May A.M., Agudo A., Buckland G., Slimani N., Rinaldi S., Couto E., et al.: Mediterranean dietary patterns and prospective weight change in participants of the EPIC-PANACEA project. Am J Clin Nutr 2010;92:912 doi:10.3945/ajen.2010.29482.

22.Russell J., Tom B., Sunmi Y., Issa Z., Kathy W., et al.: Relationship between physical activity and diet among
african-American girls. Obes Res 2004;12(S9):55S doi:10.1038/oby.2004.269.

23.Sahrai M.S., Huybrechts I., Biessy C., Gunter M.J., Romieu I., Rorres-Mejia G., Dossus L.: Association of a priori-defined dietary patterns with anthropometric measurements: A Cross-Sectional Study in Mexican Women. Nutrients 2019;11:603 doi:10.3390/nu11030603.

24.Schröder H., Marrugat J., Vila J., Covas M.I., Elosua $R$.: Adherence to the Traditional Mediterranean Diet Is Inversely Associated with Body Mass Index and Obesity in a Spanish Population. J Nutr 2004;13:3355 doi:10.1093/jn/134.12.3355.

25.Sigmundova D., Chmelik F., Sigmund E., Feltlova D., Fromel K.: Physical activity in the lifestyle of Czech university students: Meeting health recommendations, Eur J Sport Sci 2013;13(6):744 doi:10.1080/17461.2013.776638.

26.Stoody E.E., Spahn J.M., McGrane M.M., MacNeil P.C., Fungwe T.V., Altman J.M., Lyon J., Obbagy J.E., Wong Y.P.: A Series of Systematic Reviews on the Relationship between Dietary Patterns and Health Outcomes; United States Department of Agriculture: Alexandria, VA, USA 2014:501.

27. Van Poppel M.N.M., Chinapaw M.J.M., Mokkink L.B., van Mechelen W., Terwee C.B.: Physical activity questionnaires for adults: A systematic review of measurement properties. Sports Med 2010;40:565 doi.10.2165/11531930-000000000-00000.

28. Report of a WHO Expert Consultation. Waist circumference and Waist-Hip Ratio: Genewa. Available: https://www.cdc.gov/nchs/data/nhanes/nhanes_07_08/ manual_an.pdf. (Accessed:12.02.2012).

29. Wirfält E., Drake I., Wallström P.: What do review papers conclude about food and dietary patterns? Food Nutr Res 2013;57:20523. doi.10.3402/fnr.v57i0.20523.

30.www.euro.who.int/en/health-topics/disease-prevention/ nutrition/a-healthy-lifestyle/body-mass-index-bmi (Accessed: 16.01.2019).

31. Yoshida Y., Scribner R., Chen L., Broyles S., Phillippi S.,Tseng T.S.: Diet quality and its relationship with centralobesity among Mexican Americans: Findings from National Health and Nutrition Examination Survey (NHANES) 1999-2012. Pub Health Nutr 2017;20:11931202. doi: 10.1017/S1368980016003190.

Received: 23.05 .2020

Accepted: 22.06.2020 